\title{
An Examination of Component Returns and Volatility for Country-Specific Equity Funds in Emerging Markets: Evidence From Asian Financial Crisis
}

\author{
Sylvia C. Hudgins \\ Old Dominion University, Norfolk, U.S. \\ Wenjia Zhang \\ China Foreign Affairs University, Beijing, China
}

\begin{abstract}
This research aims to examine the daily return generating processes for country-specific funds in five east-Asian countries for the period 1995-2000. The effects of component returns and their volatility on the dollar denominated returns and volatility of U.S., international investors and the effects of exchange rate regimes on risk and return are also evaluated. The GARCH-M model is adopted, without the restrictive assumptions of linearity, independence, and constant conditional variance. The time frame, 1995-2000 captures a 30 months period prior to these East Asian countries aborting exchange rate stabilization/intermediate exchange rate regimes in response to the currency crisis. The decomposition of returns to holders of country-specific equity funds into the component returns due to changes in the exchange rate and the returns valued in the fund's foreign currency during a period of crisis provides additional information. This research provides evidence of the importance of examining component returns. With regards to the effects on volatility, both the conditional variances associated with the exchange rate returns and the returns denominated in the foreign currencies show some importance, especially the conditional variances associated with the returns denominated in the foreign currencies. With regards to the effects of return component, the exchange rate returns have a greater effect on the fund returns than foreign currency dominated returns.
\end{abstract}

Keywords: Asian financial crisis, equity fund, GARCH-M model, exchange rate regimes, component return

\section{Introduction}

At the beginning of the 1990s, the growth of equity funds for emerging countries allocated increasing capital from households of industrialized countries (i.e., the United States) to industrializing countries. From 1991 to 1999 in the U.S., the value of corporate equities held by mutual funds increased 10-fold, from \$309 billion in 1991 to $\$ 3.4$ trillion in 1999. In 1991, 6.4 percent of common stocks were held indirectly through mutual funds; in 1999, that figure had grown to 18 percent. As of end-1997, foreign equities comprised roughly 10 percent of U.S. equity holdings, compared with the estimated two percent in the late 1980s. ${ }^{1}$ In 1999, nearly

Sylvia C. Hudgins, Professor of Finance, Department of Finance, Old Dominion University.

Wenjia Zhang, Instructor in Finance, Department of International Economics, China Foreign Affairs University.

Correspondence concerning this article should be addressed to Wenjia Zhang, Rm 344, Main Building, No. 24, ZhanLanGuan Rd, Xicheng District, Beijing, China. E-mail: wzhang@cfau.edu.cn.

1 Flow of Funds Accounts of the United States, 1991-1999, Board of Governors of the Federal Reserve System. Retrieved from http://www.federalreserve.gov/releases/z1/current/data.htm. 
half of all U.S. households owned a mutual fund. ${ }^{2}$ Given the size and growing importance of mutual fund investors, it is important to gain a better understanding of their behavior. The risks and returns associated with these equity funds can either encourage or discourage flows to developing countries. Capital flows from equity funds are a relatively new source of funds with potentially different stability characteristics.

Five Asian countries were directly affected during the Asian financial crisis, Thailand, Korea, Indonesia, Malaysia, and Philippine, among which Thailand, Korea, Indonesia, and Philippine accepted the conditional rescue from the International Monetary Fund (IMF). The Thai baht, Korea won, Indonesia Rupiah, Malaysia Ringgit, and Philippine Peso depreciated 40.2\%, 34.1\%, 83.2\%, 39.0\%, and 37.4\% from June 1997 to July 1998, respectively (Cheetham, 1998). According to data published by the Institute of International Finance, approximately 27\% (\$35 billion) of equity investment (\$130.5 billion of net capital flows) to developing and transition economies was in the form of equity portfolio, in 1996. As financial crises developed in these economies, the proportion dropped to approximately 17\% (\$24 billion) in 1997, and 2\% (\$2.4 billion) in 1998.

Asian banks and firms accumulated large net foreign exposures in the run-up to the crisis (Eichengreen \& Husmann, 1999). In 1996, the net inflow of private capital to these five countries amounted to 93 trillion USD, more than twice of the number in 1994 (Pempel, 1999). Table 1 shows the low volatility of exchange rates and high interest rate spread, compared with the mature markets, in Asia countries led investors to believe that the authorities were insuring them against exchange risk. The consequence was a large amount of short-term foreign capital to be intermediated through the banking system, as shown in Table 2. In some countries, such as Thailand, banks were required to hedge their positions by acquiring offsetting assets in foreign currency, but they did so by making foreign-currency loans to domestic corporations, which became the repositories of the unhedged exposure. In other countries, notably Indonesia, corporations borrowed offshore directly (see Table 2), but their unhedged exposures created credit risk for domestic banks that also extended them domestic-currency loans. In both cases, the accumulation of unhedged exposures was fostered by exchange rate stability in - countries that had pegged currencies to the dollar or to baskets of currencies with a high dollar weight (World Bank, 1999, p. 61).

Table 1

Macroeconomic Indicators Related to Unhedged Foreign Currency Borrowings in East Asia, January 1991-June 1997

\begin{tabular}{lllc}
\hline Country & Interest rate spread & Average annual appreciation vs. U.S. \$ & Exchange rate volatility \\
\hline Indonesia & 11.5 & -3.8 & 0.7 \\
Korea & 4.1 & -3.2 & 3.4 \\
Malaysia & 1.6 & 1.2 & 2.6 \\
Philippines & 6.5 & 0.9 & 3.8 \\
Thailand & 4 & -0.3 & 1.2 \\
Germany & 1.2 & -2.0 & 6.4 \\
Thailand & -2.2 & 2.5 & 10.7
\end{tabular}

Note. Source: World Bank, 1999.

\section{Macroeconomic Indicators and Foreign Exposure Before the Asian Crisis}

Tables 1 and 2 summarize the macroeconomic indicators for unhedged borrowing, foreign exposure of banks and finance companies, and corporate foreign and domestic debt composition.

\footnotetext{
2 The Investment Company Institute, Mutual Fund Factbook, 2000, reports as of year-end 1999, 48.4 million households own mutual funds. In December 1998, there were roughly 103 million households in the U.S..
} 
Table 1 shows interest rate spread equals local deposit rate less LIBOR (U.S. \$) for East Asian countries. Interest rate spread in percentage points. The average annual appreciation is calculated relative to the U.S. dollar (in percent); a minus sign indicates depreciation. Exchange rate volatility refers equals to the standard deviation of an percentage deviation of exchange rate (U.S. \$) from regression on a time trend.

Table 2 shows the foreign exposure of banks and finance companies, measured by the ratio of foreign liabilities to M2 and the ratio of foreign liabilities to assets, and corporate foreign, and domestic debt composition in 1996.

Table 2

Foreign Exposure and Debt Composition

\begin{tabular}{|c|c|c|c|c|c|c|c|c|c|c|}
\hline \multirow[t]{2}{*}{ Country } & \multicolumn{3}{|c|}{$\begin{array}{l}\text { (1) Ratio of foreign } \\
\text { liabilities to M2 (\%) }\end{array}$} & \multicolumn{3}{|c|}{$\begin{array}{c}\text { (2) Ratio of foreign } \\
\text { liabilities to assets (\%) }\end{array}$} & \multicolumn{2}{|c|}{ (3) Foreign debt } & \multicolumn{2}{|c|}{ (4) Domestic debt } \\
\hline & 1990 & 1994 & 1996 & 1990 & 1992-1996 & 1996 & Short-term & Long-term & Short-term & Long-term \\
\hline Indonesia & 1.2 & 7.0 & 3.2 & 108 & 193 & 143 & 20.5 & 19.6 & 31.4 & 28.5 \\
\hline Korea & 4.4 & 8.3 & 14.1 & 140 & 149 & 174 & 29.4 & 17.0 & 27.7 & 25.8 \\
\hline Thailand & 6.1 & 25.1 & 32.8 & 265 & 519 & 775 & 29.6 & 12.3 & 32.0 & 26.1 \\
\hline Malaysia & - & - & - & - & - & - & 32.1 & 11.0 & 35.7 & 21.2 \\
\hline Philippines & - & - & - & - & - & - & 19.7 & 21.3 & 25.5 & 33.5 \\
\hline
\end{tabular}

Note. Source: IMF International Financial Statistics and Asian Development Bank, 1999.

These five countries experienced a net private capital outflow of 24.6 trillion USD in 1998. The financial condition of these countries deteriorated. The stock market and foreign exchange market volatile severely. The variability illustrated in these numbers provides the incentive to learn more about the sources of instability during times of financial crises. Portfolio holdings are governed by investors' perceptions of risk and returns given their risk-aversion. This research utilizes the market environment at the time of the Asian financial crisis to examine the daily return generating processes for six country-specific closed end funds ${ }^{3}$ (see Table 3 ) in these five east-Asian countries (Indonesia, Korea, Malaysia, the Philippines, and Thailand) for the period 1995-2000 with the focus on changing exchange rate regimes.

Table 3 presents the list of funds in the sample, along with their ticker symbols, initial public offering (IPO) dates, number of observations, and the specific foreign market index used in this study. The sample starts from January 1, 1995, and ends with December 31, 2000.

Table 3

Sample of Closed-End Country Funds

\begin{tabular}{lllll}
\hline Fund & Ticker (exchange) & IPO date & Number of observations & Foreign stock index \\
\hline Indonesia & IF(NYSE) & $03 / 01 / 1990$ & 1,458 & Jakarta SE Composite \\
Korea & KF(NYSE) & $08 / 22 / 1984$ & 1,485 & KOSPI \\
Malaysia fund & MAY(NYSE) & $05 / 12 / 1987$ & 1,484 & Malaysia FTSE Bursa Malaysia Index \\
First Philippines & FPF(NYSE) & $11 / 08 / 1989$ & 1,471 & Philippine SE Industrial Index (PSIND) \\
Thai fund & TH(NYSE) & $02 / 17 / 1988$ & 1,410 & Thailand SET General Index \\
Thai capital fund & TF(NYSE) & $05 / 22 / 1990$ & 1,481 & Thailand SET General Index \\
\hline
\end{tabular}

\footnotetext{
${ }^{3}$ There were only six U.S. closed end funds, investing in these five countries, traded on the stock exchange around the 1997 Asian crisis.
} 
An overview of the paper follows. Section two discusses the related literature and develops the hypotheses. Section three describes the sources and distributional properties of the data. Section four interprets of the empirical results concerning the hypothesis tests. Finally, Section five concludes.

\section{Literature Review and Hypothesis Development}

\section{Decomposition of Country Fund Return}

Exchange rates have a broad impact on macroeconomic conditions of a country. Since real goods prices are sticky, changes in nominal exchange rates lead to changes in real exchange rates, which directly affect international competitiveness of an export industry and costs of imported goods and raw materials. (Tsutsui \& Hirayama, 2004, p. 473)

Since the late 1990s, the emerging market economies have become more open on capital account and are following freer exchange rate policies. By adopting a scale of 3, Saxena (2008) found the average index of capital mobility increased from 1.61 during 1975-1999 to 2.59 between 2000 and 2006 for 17 emerging economies in Asia, Latin America, and South Africa. At the same time, the proportion of observations on exchange rate regimes classified as floating increased from $68 \%$ to $73 \%$.

The relaxation of capital controls means that previously unexploited arbitrage opportunities are now filled. Taylor and Tonks (1989) assessed the impact of the abolition of U.K. exchange control on the degree of integration of U.K. and overseas stock markets, and find that although there is no significant increase in the correlation of short-run stock market returns post 1979, there is a marked increase in markets comovement in the long run.

The cointegration of two sets of stock market returns suggests that in the long run these returns are highly correlated, implying that international diversification has little effects in reducing long-run portfolio risk. This result is also confirmed by the findings of Grubel and Fadner (1971), Ripley (1973), and Panton, Lessig, and Joy (1976) suggesting long-run covariances between stock markets are higher than those in the short run, i.e., the benefits from international diversification will be reduced in the long run.

Therefore, it would be desirable to investigate how the exchange rates, as well as exchange rate regimes, affect the pricing of sovereign funds, for they are in nature an important tool for international diversification. With this primary motivation, we ground this research on the decomposition of returns to holders of country-specific equity funds ${ }^{4}$. Specifically, the total return of each equity fund equal the dollar changes in the exchange rate plus the returns valued in the foreign currency plus the cross-product term as follows ${ }^{5}$ :

$$
R_{\$(t)}=R_{F X(t)}+R_{F C(t)}+\left(R_{F X(t)} * R_{F C(t)}\right)
$$

where $R_{\$(t)}$ stands for the return from holding a country specific fund (e.g., Thai fund) denominated in dollars, $R_{F X(t)}$ for the return from changes in the foreign exchange rate (i.e., the number of dollars exchanged per baht), and $R_{F C(t)}$ for the return denominated in the foreign currency (i.e., Thai baht) from holding a portfolio of underlying securities.

Equation (1) breaks-down total returns into a portfolio component that captures the opportunities and decisions of firm managers for equities held in the underlying assets ( $\left.R_{F C(t)}\right)$ and a foreign-exchange component $\left(R_{F X(t)}\right)$ that captures the effects of changes in exchange rates. If we assume the cross-product term to be insignificant, then the returns from holding a country-specific fund denominated in dollars could be

\footnotetext{
${ }^{4}$ This idea is also inspired by Tsutsui and Hirayama (2004)'s idea of distinguishing between stock returns measured in local currency and those measured in dollars to test whether exchange rate component plays a significant role in international stock price comovements.

${ }^{5}$ Since $1+R_{\$(t)}=\left(1+R_{f x(t)}\right) *\left(1+R_{f c(t)}\right)=1+R_{f x(t)}+R_{f c(t)}+\left(R_{f x(t)} * R_{f c(t)}\right)$, we get $R_{\$(t)}=R_{f x(t)}+R_{f c(t)}+\left(R_{f x(t)} * R_{f c(t)}\right)$.
} 
viewed as the sum of returns from changes in the foreign exchange rate and returns from the change in the value of the underlying securities denominated in the foreign-country's currency ${ }^{6}$.

Since share transactions of underlying assets in Asian countries are conducted in the foreign country currencies, it is natural for the investors to care about the performance of both the U.S. and the foreign country stock market, measured by the index. So, it would be meaningful to include the stock market performance in the return generating analysis. A number of studies have shown that country fund returns are sensitive to U.S. and foreign stock index returns, specifically focusing on the short-term (country fund return generating function) or the long-term (cointegration) relation of country fund returns and their comparable return series (e.g., Bekaert \& Urias, 1996, 1999; Ben-Zion, Choi, \& Hauser, 1996; Chang, Eun, \& Kolodny, 1995; Chiang \& Kim, 2003; Hardouvelis, LaPorta, \& Wizman, 1994; Lee \& Hong, 2002; Richard \& Wiggins, 2000).

Therefore, we test the correlation between foreign-country component returns and foreign-country index returns, and assume that if the foreign-country portfolio component return is highly correlated with the stock market index return, the stock market information has been contained in the foreign-country component return and thereby only keep the foreign-country component return in our regression. Table 4 shows the correlation between daily foreign-country portfolio component returns and foreign-country stock market index returns. All six correlations between the foreign-country portfolio component returns and foreign-country stock market index returns are significantly different from zero at $1 \%$ level, and four out of six correlations between the foreign-country portfolio component returns and NYSE index returns, where the CRSP NYSE value-weighted market index return from CRSP database is adopted, are significantly different from zero at $1 \%$.

Table 4 reports the correlation coefficients between daily foreign-country and U.S. stock market index return and equity fund return measured in foreign currency $\left(R_{F C(t)}\right)$ in each country during 1995-2000. The foreign-country stock market index returns are calculated based on the listed indexes. And the U.S. stock market returns adopt NYSE Value-Weighted Market Index returns from CRSP database.

Table 4

Correlation Between Foreign-Country Portfolio Component Return and Foreign-Country/U.S. Stock Market Index Returns

\begin{tabular}{|c|c|c|c|c|c|c|}
\hline Country specific stock market index & $\begin{array}{l}\text { Thai Fund } \\
\text { Inc. }\end{array}$ & $\begin{array}{l}\text { Thai Capital } \\
\text { Fund Inc. }\end{array}$ & $\begin{array}{l}\text { First Philippine } \\
\text { Fund }\end{array}$ & $\begin{array}{l}\text { Malaysia } \\
\text { Fund Inc. }\end{array}$ & $\begin{array}{l}\text { Korea } \\
\text { Fund Inc. }\end{array}$ & $\begin{array}{l}\text { Indonesia } \\
\text { Fund Inc. }\end{array}$ \\
\hline Thailand SET General Index & $0.334^{* * *}$ & $0.334^{* * *}$ & & & & \\
\hline Philippine SE Industrial Index (PSIND) & & & $0.321^{* * *}$ & & & \\
\hline Malaysia: FTSE Bursa Malaysia Index & & & & $0.257^{* * *}$ & & \\
\hline Korea SE Stock Price Index (KOSPI) & & & & & $0.469^{* * *}$ & \\
\hline Indonesia: Jakarta SE Composite Index (JKSED) & & & & & & $0.172^{* * *}$ \\
\hline U.S.: CRSP NYSE Value-Weighted Market Index & $0.241^{* * * *}$ & $0.236^{* * *}$ & $0.354^{* * *}$ & $0.262^{* * *}$ & -0.028 & -0.016 \\
\hline
\end{tabular}

Notes. ${ }^{* * * * * *}$, and ${ }^{*}$ indicate significance at the $1 \%, 5 \%$, and $10 \%$ levels, respectively.

Investments in foreign equities or country-specific funds can gain/lose money in two ways: (1) through a decline in the value of the portfolio in the foreign country currency (i.e., Thai baht) and (2) through devaluation of the foreign currency relative to the dollar. The effects of these two components are illustrated during the

\footnotetext{
${ }^{6}$ Since these close-end country funds are traded in U.S., "Foreign country" here refers to the country where the fund invests by its name. For example, standing in the viewpoint of U.S. investors, "foreign country" of Thai Fund refers to Thailand.
} 
Asian crisis by 1997 statistics. Table 5 specifies the annual returns ${ }^{7}$ of country-specific funds and the component returns, attributed to the foreign-country portfolios and changes in the exchange rates. Specifically, as the countries transferred the risk of rate fluctuations to outside investors with the movement to market-driven floating exchange rates, the cross-sectional total returns ranged from $-66.79 \%$ for the Thai fund to $-52.56 \%$ for the Indonesia fund. In the summer of 1997, these countries moved to market-determined exchange rates and the annual exchange rate component ranged from $-55.31 \%$ for Indonesia to $-34.41 \%$ for the Philippines. The returns denominated in the countries' foreign currencies ranged from $+6.16 \%$ for Indonesia to $-40.69 \%$ for Malaysia. Indonesia and Korea have maintained floating rates to date; the Philippines and Thailand enhanced their regulation again since 1998; and Malaysia returned to a stabilization policy in September 1998.

Table 5 displays the annualized fund returns $\left(R_{s(t)}\right)$ of the six country-specific funds and the component returns, attributed to the changes in the exchange rates $\left(R_{F X(t)}\right)$ and foreign-country portfolios $\left(R_{F C(t)}\right)$. The sample starts from January 1, 1995, and ends with December 31, 2000.

Table 5

Annual Returns of Country-Specific Funds and the Component Returns Attributed to the Foreign-Country Portfolios and Changes in the Exchange Rates

\begin{tabular}{|c|c|c|c|c|c|c|}
\hline Country-specific funds and component returns & 1995 & 1996 & 1997 & 1998 & 1999 & 2000 \\
\hline \multicolumn{7}{|l|}{ Thai Fund Inc. (TTF) } \\
\hline Returns for U.S. Investor $\left(R_{\$(t)}\right)$ & $-0.560 \%$ & $-26.970 \%$ & $-66.790 \%$ & $6.160 \%$ & $26.260 \%$ & $-67.500 \%$ \\
\hline Foreign Exchange Component ( $\left.R_{F X(t)}\right)$ & $-0.310 \%$ & $-1.700 \%$ & $-44.180 \%$ & $32.160 \%$ & $-3.630 \%$ & $-13.430 \%$ \\
\hline Foreign-Country Portfolio Component $\left(R_{F C(t)}\right)$ & $0.250 \%$ & $-25.710 \%$ & $-40.510 \%$ & $-19.670 \%$ & $31.020 \%$ & $-61.490 \%$ \\
\hline \multicolumn{7}{|l|}{ Thai Capital Fund Inc. (TF) } \\
\hline Returns for U.S. Investor $\left(R_{\$(t)}\right)$ & $-5.260 \%$ & $-40.300 \%$ & $-62.500 \%$ & $-8.820 \%$ & $23.810 \%$ & $-66.670 \%$ \\
\hline Foreign Exchange Component ( $\left.R_{F X(t)}\right)$ & $-0.310 \%$ & $-1.700 \%$ & $-44.180 \%$ & $32.160 \%$ & $-3.630 \%$ & $-13.430 \%$ \\
\hline Foreign-Country Portfolio Component $\left(R_{F C(t)}\right)$ & $-5.740 \%$ & $-39.260 \%$ & $-32.820 \%$ & $-31.010 \%$ & $28.470 \%$ & $-60.260 \%$ \\
\hline \multicolumn{7}{|l|}{ Indonesia Fund Inc. (IF) } \\
\hline Returns for U.S. Investor $\left(R_{\$(t)}\right)$ & $-13.830 \%$ & $-8.240 \%$ & $-52.560 \%$ & $-28.570 \%$ & $64.150 \%$ & $-72.530 \%$ \\
\hline Foreign Exchange Component $\left(R_{F X(t)}\right)$ & & $-2.650 \%$ & $-55.310 \%$ & $-24.990 \%$ & $11.330 \%$ & $-26.740 \%$ \\
\hline Foreign-Country Portfolio Component $\left(R_{F C(t)}\right)$ & & $-5.740 \%$ & $6.160 \%$ & $-4.770 \%$ & $47.450 \%$ & $-60.780 \%$ \\
\hline \multicolumn{7}{|l|}{ First Philippine Fund (FPF) } \\
\hline Returns for U.S. Investor (Returns) & $-28.390 \%$ & $18.060 \%$ & $-54.960 \%$ & $-14.550 \%$ & $-4.400 \%$ & $-46.000 \%$ \\
\hline Foreign Exchange Component ( $\left.R_{F X(t)}\right)$ & & $-0.090 \%$ & $-34.410 \%$ & $4.890 \%$ & $9.990 \%$ & $-20.270 \%$ \\
\hline Foreign-Country Portfolio Component $\left(R_{F C(t)}\right)$ & & $18.170 \%$ & $-31.330 \%$ & $-18.530 \%$ & $5.150 \%$ & $-32.270 \%$ \\
\hline \multicolumn{7}{|l|}{ Korea Fund Inc. (KF) } \\
\hline Returns for U.S. Investor $\left(R_{\$(t)}\right)$ & $0.000 \%$ & $-32.390 \%$ & $-56.610 \%$ & $33.330 \%$ & $76.620 \%$ & $-36.000 \%$ \\
\hline Foreign Exchange Component $\left(R_{F X(t)}\right)$ & $2.080 \%$ & $-7.940 \%$ & $-50.480 \%$ & $40.940 \%$ & $4.520 \%$ & $-11.290 \%$ \\
\hline Foreign-Country Portfolio Component $\left(R_{F C(t)}\right)$ & $-2.040 \%$ & $-26.580 \%$ & $-10.930 \%$ & $-0.270 \%$ & $73.310 \%$ & $-30.750 \%$ \\
\hline \multicolumn{7}{|l|}{ Malaysia Fund Inc. (MAY) } \\
\hline Returns for U.S. Investor $\left(R_{\$(t)}\right)$ & $-2.158 \%$ & $17.600 \%$ & $-61.470 \%$ & $-41.070 \%$ & $68.660 \%$ & $-45.946 \%$ \\
\hline Foreign Exchange Component ( $\left.R_{F X(t)}\right)$ & $0.410 \%$ & $0.630 \%$ & $-35.030 \%$ & $4.080 \%$ & $0.010 \%$ & $-0.021 \%$ \\
\hline Foreign-Country Portfolio Component $\left(R_{F C(t)}\right)$ & $-2.557 \%$ & $16.870 \%$ & $-40.690 \%$ & $-43.370 \%$ & $68.640 \%$ & $-46.893 \%$ \\
\hline
\end{tabular}

\footnotetext{
${ }^{7}$ While our research is based on daily data, we would like to show a big picture here first using annual returns calculated on daily returns.
} 
The importance of breaking down the total returns into the exchange rate component and the country component is derived from the differing potentials to diversify away risk in the portfolio context and to hedge risk through means such as foreign exchange futures.

\section{Methodology}

In econometrics, autoregressive conditional heteroskedasticity (ARCH) and generalized autoregressive conditional heteroskedasticity (GARCH) models are often used to characterize and model observed time series, such as stock returns and exchange rates. The ARCH model developed by Engle (1982) is a special case of the broader GARCH model introduced by Bollerslev (1986) and extended to ARCH and GARCH in mean (ARCH-M and GARCH-M) models by Engle, Lilien, and Robins (1987). The GARCH $(p, q)$-M model, can be generalized by the following group equations:

$$
\begin{gathered}
Y_{(t)}=\beta X_{(t)}+\phi \sigma^{2}{ }_{(t)}+\varepsilon(t) \\
\sigma^{2}{ }_{(t)}=\alpha_{0}+\sum_{i=1}^{p} \alpha_{i} \varepsilon^{2}{ }_{(t-i)}+\sum_{i=1}^{q} \lambda_{i} \sigma^{2}{ }_{(t-i)}+\pi Z_{(t-1)} \\
\varepsilon_{(t)} \mid I_{(t-1)} \sim N\left(0, \sigma^{2}\right)
\end{gathered}
$$

where $Y_{(t)}$ is the dependent variable in the mean equation (i.e., return on the closed end mutual fund); $X_{(t)}$ in the mean equation and $Z_{(t)}$ in the variance equation are vectors of predetermined/exogenous variables including component lagged returns and dummy variables for the exchange rate regime; $\sigma_{(t)}^{2}$ is referred to as the conditional variance which is the one-period ahead forecast variance based on past information; $\varepsilon(t)$ is the random error, and $I_{(t-1)}$ is the information set. $\beta, \phi, \alpha_{0}, \alpha_{i}, \lambda_{i}$, and $\pi$ are parameter vectors/scalars and the subscript $t$ is a time index. $p$ and $q$ describe the order of ARCH and GARCH terms respectively.

For financial data, the variance of the error term varies over time in a manner that depends on the size of past errors. The GARCH $(p, q)$ incorporates corrections for this form of heteroskedasticity providing more efficient parameter estimates for the explanation of returns and a methodology for the modeling of volatility. The GARCH-in-Mean (GARCH-M) model as developed in Engle, Lilien, and Robins (1987) integrates expected risk in the regression equation by including the conditional variance as a proxy for this risk. Based on financial theory, one would expect the fund's return to be proportional to the fund's expected risk exposure. GARCH-M $(1,1)$ has been chosen to examine the questions put forth in this paper.

To examine the relationship between daily dollar returns for country specific equity, volatility, and the effect of changing exchange rate regimes on returns and volatility, our model incorporates the component returns associated with changes in the exchange rates, movements in the prices denominated in the foreign currency. It is structured as follows ${ }^{8}$ :

$$
\begin{aligned}
& R_{\$(t)}=\beta_{1}+\beta_{2} R_{F C(t-1)}+\beta_{3} R_{F X(t-1)}+\phi \sigma_{(t)}^{2}+\beta_{4} \text { Float }_{(t)}+\beta_{5} \text { Fixed }_{(t)}+\varepsilon_{(t)} \\
& \sigma^{2}(t)=\alpha_{0}+\alpha_{1} \varepsilon_{(t-1)}^{2}+\lambda_{1} \sigma_{(t-1)}^{2}+\pi_{1} \text { Float }_{(t)}+\pi_{2} \text { Fixed }_{(t)}+\pi_{3} \sigma_{F C}^{2}(t-1)+\pi_{4} \sigma_{F X}^{2}(t-1)
\end{aligned}
$$

\footnotetext{
${ }^{8}$ We start with the following group equations:

$R_{\$(t)}=\beta_{1}+\beta_{2} R_{\$(t-1)}+\phi \sigma^{2}(t)+\beta_{3}$ Float $_{(t)}+\beta_{4}$ Fixed $_{(t)}+\varepsilon(t)$

$\sigma^{2}{ }_{(t)}=\alpha_{0}+\alpha_{1} \varepsilon^{2}{ }_{(t-1)}+\lambda_{1} \sigma^{2}(t-1)+\pi_{1}$ Float $_{(t)}+\pi_{2}$ Fixed $_{(t)}$

$\varepsilon_{(t)} \mid I_{(t-1)} \sim N\left(0, \sigma^{2}\right)$
}

using a traditional approach. Similar hypotheses are developed and proved. Results are not reported, but available upon request. 


$$
\varepsilon_{(t)} \mid I_{(t-1)} \sim N\left(0, \sigma^{2}\right)
$$

In equation (3a), $R_{\$(t)}$ is the daily return from holding a country specific fund (e.g., Thai fund) denominated in dollars; $R_{F C}$, the daily return from holding a country specific fund denominated in the foreign country's currency; $R_{F X}$, the daily return from changes in the exchange rate; $\sigma_{(t)}^{2}$ is the conditional variance for the equity fund, the one-period ahead forecast variance based on past information; $\varepsilon(t)$ is the random error. Float $_{(t)}$ is an explanatory dummy variable that equals 1 for a floating exchange rate regime, 0 for intermediate exchange rate regime and fixed exchange rate regime ${ }^{9}$. To catch the difference between fixed exchange rate regime and intermediate/float exchange rate regime, we introduce the second dummy variable Fixed ${ }_{(t)}$, which equals 1 for fixed exchange rate regime and 0 otherwise.

The conditional variance equation (3b) includes information about: (1) volatility from the previous period via the ARCH term $\left(\varepsilon^{2}{ }_{(t-1)}\right)$; (2) the last period's forecast of variance associated with returns in the equity fund $\left(\sigma_{(t-1)}^{2}\right)$; (3) the last period's forecast of variance associated with returns in dollars $\sigma_{F C}^{2(t-1)}$; (4) the last period's forecast of variance associated with movements in the exchange rate $\left(\sigma_{F X}^{2}{ }^{(t-1)}\right)$; and (5) two exchange rate regime dummy variables Float $_{(t)}$ and Fixed $_{(t)}$. This component model is estimated using maximum likelihood.

\section{Hypotheses Development}

This component model is structured to allow the testing of a number of hypotheses. The structure of hypotheses resembles and is modeled after Elyasiani and Mansur's (1998) examination of the sensitivity of bank stock returns distribution to changes in the level and volatility of interest rates. Four hypotheses are developed to examine the effects of the volatility of exchange rates, the volatility of returns in the equity fund's foreign currency, and shifts of exchange rate regimes. Hypothesis one is composed of two alternative hypotheses.

H1a: The return generating process follows an ARCH-M specification: $\lambda_{1}=\pi_{3}=\pi_{4}=\pi_{5}=0$. Volatility is time dependent with a short memory; however, it is priced.

H1b: The return generating process follows a GARCH specification: $\phi=0$. The return generating process has a long memory and volatility is not a significant factor in pricing the country-specific equity funds.

H2: The application of different exchange rate regimes had no effect on the risk and return of country-specific equity funds. So, the choice of exchange rate regimes does not affect the risk and returns of these funds: $\phi=\beta_{4}=\beta_{5}=\pi_{1}=\pi_{2}=0$.

H3: Exchange rate effects have no impact on the country-specific fund's return generating process: $\beta_{3}=\pi_{4}$ $=0$.

H4: Foreign country effects have no impact on the country-specific fund's risk and return: component model: $\beta_{2}=\pi_{3}=0$.

\footnotetext{
9 There are often contradictions between the de jure exchange rate regime (each government's own declaration of its exchange rate regime) and the way the de facto exchange rate policy is conducted (Kim \& Lee, 2008). For example, a regime that is classified as floating (independently or managed) might be in effect a peg, defending its exchange rate within a narrow margin around a fixed rate. Recent studies, Reinhart and Rogoff (2004) and Levy-Yeyati and Sturzenegger (2005), highlighted the contrast between countries' official declarations concerning their exchange rate regimes and the way they actually conduct exchange rate policy. The de facto classifications of exchange rate regimes for East Asian countries by Reinhart and Rogoff (2004) are reported in Appendix A. Because during the period we investigate, Indonesia and Korea did not experience fixed exchange regime, there is only one dummy ( Float $_{(t)}$ ) used for analysis of these two countries.
} 


\section{Data}

\section{Data Sources}

The five East Asian countries changing their exchange rate regimes during the period 1995-2000 ${ }^{10}$ include: Indonesia, Korea, Malaysia, Philippine, and Thailand (Kim \& Lee, 2008). The six U.S. equity funds investing in these countries are the focus of this analysis. Daily closing returns ${ }^{11}$ for the six East-Asian country-specific funds are collected from the Center for Research in Security Prices (CRSP) database. One closed-end country-specific fund is traded in the U.S. for Indonesia (the Indonesia Fund (IF)), Korea Fund Inc. (KF), Malaysia (the Malaysia Fund (MAY)), and the Philippines (the First Philippine Fund (FPF)); while two funds are traded for Thailand, the Thai Capital Fund (TF) and the Thai Fund (TTF) (see Table 3).

The daily exchange rates for Indonesia, Korea, Malaysia, the Philippines, and Thailand are obtained from the International Financial Statistics Database. The exchange rates are used to calculate the returns from investing a dollar in the foreign currency. The dollar-denominated price data for the country-specific funds and the exchange rates are used to derive the returns denominated in the foreign currency. Using this data, components in equation (1) are calculated as illustrated in equation (4):

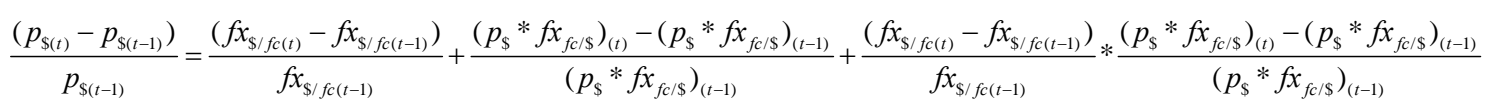

where $p_{\S}$ stands for price of the country-specific fund in dollars at time $t$ or $t-1, f x_{s / f c}$ for the number of dollars exchange per unit of foreign currency at time $t$ or $t-1$, and $f x_{f c / s}$ for the number of units of foreign currency per dollar at time $t$ or $t-1$.

\section{Distributional Properties of the Data}

Table 6 provides a number of descriptive statistics to provide you information concerning the distributional properties of the data. You will find the mean return, median return, maximum return, minimum return, standard deviation, skewness, kurtosis, the Ljung-Box $Q$-statistics for order 1 and order 10, the Jarque-Bera normality test, and the Augmented Dickey-Fuller Test. The null hypothesis of normality is rejected at the $1 \%$ level using the Jarque-Bera test statistic. The skewness and kurtosis measures indicate that the non-normality can in part be attributed to leptokurtosis. This has been found in both stock return and foreign exchange data. This indicates that the GARCH model is more appropriate than the standard statistical models. The Ljung-Box $Q$-statistics indicate the presence of autocorrelation. Whereas, a comparison of the Ljung-Box $Q$-statistics for returns versus squared returns indicates the presence of conditional heteroskedasticity. Finally the Augmented Dickey-Fuller tests indicate that all six data series are stationary. In aggregate, this descriptive information indicates that the family of GARCH models is appropriate for modeling the returns of these East Asian equity funds.

Table 6 displays descriptive statistics for the distributional properties of the six funds. For each daily fund return $\left(R_{\$}(t)\right.$, the mean value, median value, maximum value, minimum value, standard deviation, skewness, kurtosis, the Ljung-Box $Q$-statistics for order 1 and order 10, the Jarque-Bera normality test, and the Augmented Dickey-Fuller test results are listed. $L-B_{x}(1)$ : Ljung-Box $Q$-statistic for the null hypothesis that

\footnotetext{
10 The time frame, 1995-2000 captures a 30 months period prior to these East Asian countries aborting exchange rate stabilization/intermediate exchange rate regimes in response to the currency crisis, and is long enough to cover all the exchange regime shifts around the Asian financial crisis in those countries (see Appendix A).

11 Sovereign funds are traded on every U.S. trading day, except the weekends and U.S. holidays.
} 
there is no autocorrelation up to order 1 . Specifically, $L-B_{x}(10)$ stands for Ljung-Box $Q$-statistic for the null hypothesis that there is no autocorrelation up to order $10 ; L-B_{x x}(1)$ stands for Ljung-Box $Q$-statistic (squared data) for the null hypothesis that there is no autocorrelation up to order $1 ; L-B_{x x}(10)$ stands for Ljung-Box $Q$-statistic (squared data) for the null hypothesis that there is no autocorrelation up to order 10; Jarque-Bera test statistic is for the null hypothesis that the data is normally distributed; ADF test statistic stands for The Augmented Dickey-Fuller Test including two lags with the null hypothesis that the data is non-stationary or contains a unit root.

Table 6

Distributional Statistics on Daily Returns of Country-Specific Funds (1995-2000)

\begin{tabular}{|c|c|c|c|c|c|c|}
\hline Statistic & Thai Fund Inc. & $\begin{array}{l}\text { Thai Capital } \\
\text { Fund Inc. }\end{array}$ & $\begin{array}{l}\text { Indonesia Fund } \\
\text { Inc. }\end{array}$ & $\begin{array}{l}\text { First Philippine } \\
\text { Fund }\end{array}$ & Korea Fund Inc. & $\begin{array}{l}\text { Malaysia Fund } \\
\text { Inc. }\end{array}$ \\
\hline Mean & -0.001 & -0.001 & -0.001 & -0.001 & 0.000 & 0.000 \\
\hline Median & 0.000 & 0.000 & 0.000 & 0.000 & 0.000 & 0.000 \\
\hline Maximum & 0.185 & 0.241 & 0.281 & 0.178 & 0.159 & 0.279 \\
\hline Minimum & -0.141 & -0.171 & -0.138 & -0.116 & -0.140 & -0.153 \\
\hline Std. Dev. & 0.029 & 0.031 & 0.035 & 0.025 & 0.028 & 0.027 \\
\hline Skewness & 0.799 & 0.937 & 0.939 & 0.683 & 0.290 & 1.233 \\
\hline Kurtosis & 8.110 & 10.520 & 9.477 & 8.765 & 6.637 & 14.113 \\
\hline $\mathrm{L}-\mathrm{B}_{\mathrm{x}}(1)$ & $11.348^{* * *}$ & 0.8464 & 0.1551 & 0.5780 & 0.0032 & $5.2017^{* *}$ \\
\hline ( $p$-value) & $(0.001)$ & $(0.358)$ & $(0.694)$ & $(0.447)$ & $(0.955)$ & $(0.023)$ \\
\hline $\mathrm{L}-\mathrm{B}_{\mathrm{x}}(10)$ & $37.489^{* * *}$ & $24.777^{* * *}$ & $22.607^{* *}$ & $33.048^{* * *}$ & $42.625^{* * *}$ & $19.856^{* *}$ \\
\hline ( $p$-value) & $(0.000)$ & $(0.006)$ & $(0.012)$ & $(0.000)$ & $(0.000)$ & $(0.031)$ \\
\hline L-B ${ }_{x x}(1)$ & $45.617^{* * * *}$ & $47.743^{* * *}$ & $30.863^{* * * *}$ & $172.81^{* * *}$ & $152.37^{* * *}$ & $37.585^{* * *}$ \\
\hline ( $p$-value) & $(0.000)$ & $(0.000)$ & $(0.000)$ & $(0.000)$ & $(0.000)$ & $(0.000)$ \\
\hline L-B ${ }_{x x}(10)$ & $140.03^{* * *}$ & $129.84^{* * *}$ & $123.48^{* * *}$ & $334.65^{* * *}$ & $731.14^{* * *}$ & $124.80^{* * *}$ \\
\hline ( $p$-value) & $(0.000)$ & $(0.000)$ & $(0.000)$ & $(0.000)$ & $(0.000)$ & $(0.000)$ \\
\hline $\begin{array}{l}\text { Jarque-Bera } \\
\text { (probability) }\end{array}$ & $\begin{array}{l}1769.108^{* * *} \\
(0.000)\end{array}$ & $\begin{array}{l}3706.623^{\text {*** }} \\
(0.000)\end{array}$ & $\begin{array}{l}2763.152^{* * *} \\
(0.000)\end{array}$ & $\begin{array}{l}2151.677^{* * *} \\
(0.000)\end{array}$ & $\begin{array}{l}839.086^{* * *} \\
(0.000)\end{array}$ & $\begin{array}{l}8012.536^{* * *} \\
(0.000)\end{array}$ \\
\hline ADF test statistic & -35.146 & -39.309 & -37.550 & -39.024 & -29.235 & -36.271 \\
\hline
\end{tabular}

Notes. The sample starts from January 1, 1995, and ends with December 31, 2000. ${ }^{* * *},{ }^{* *}$, and ${ }^{*}$ indicate significance at the $1 \%$, $5 \%$, and $10 \%$ levels, respectively.

\section{Interpretation of Equation Coefficients and Hypothesis Tests}

Table 7 presents the results for GARCH-M model (equations 5(a), 5(b), and 5(c)) using maximum likelihood estimation. Table 8 provides complementary check for the model when NYSE returns and its conditional volatility are considered. Engle's LM test against the first-order serial correlation in the residuals is specified. This table presents the log likelihood value of each equation, which is used to construct the likelihood ratio (LR) tests. Table 9 presents the LR tests for each hypothesis.

Table 7 presents the results for two GARCH-M models using maximum likelihood estimation. The sample starts from January 1, 1995, and ends with December 31, 2000. Log likelihood value of each equation is reported at the bottom. Engle's LM test against first-order serial correlation in the residuals is also specified.

The coefficients in Table 7 are consistent with the following functions:

$$
R_{\$(t)}=\beta_{1}+\beta_{2} R_{F C(t-1)}+\beta_{3} R_{F X(t-1)}+\phi \sigma^{2}(t)+\beta_{4} \text { Float }_{(t)}+\beta_{5} \text { Fixed }_{(t)}+\varepsilon(t)
$$




$$
\begin{gathered}
\sigma^{2}(t)=\alpha_{0}+\alpha_{1} \varepsilon^{2}{ }_{(t-1)}+\lambda_{1} \sigma^{2}{ }_{(t-1)}+\pi_{1} \text { Float }_{(t)}+\pi_{2} \text { Fixed }_{(t)}+\pi_{3} \sigma_{F C}^{2} C^{(t-1)}+\pi_{4} \sigma_{F X}^{2}(t-1) \\
\varepsilon_{(t)} \mid I_{(t-1)} \sim N\left(0, \sigma^{2}\right)
\end{gathered}
$$

Table 7

Maximum Likelihood Estimates of Component GARCH-M $(1,1)$

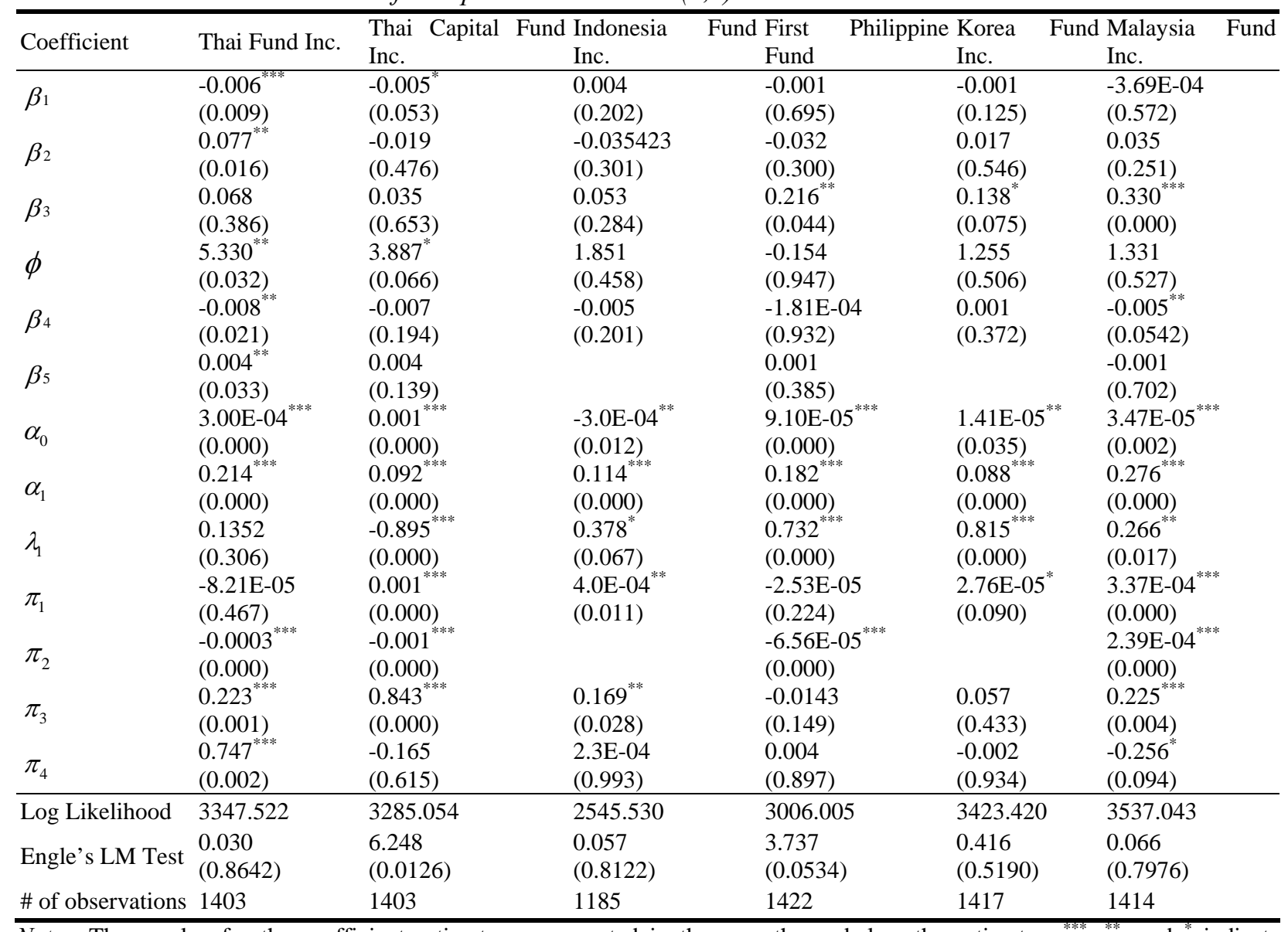

Notes. The $p$-value for the coefficient estimates are reported in the parentheses below the estimates. ${ }^{* * *},{ }^{* *}$, and $^{*}{ }^{*}$ indicate significance at the $1 \%, 5 \%$, and $10 \%$ levels, respectively.

The coefficients in Table 8 are consistent with the following functions:

$$
\begin{gathered}
R_{\$(t)}=\beta_{1}+\beta_{2} R_{F C(t-1)}+\beta_{3} R_{F X(t-1)}+\phi \sigma_{(t)}^{2}+\beta_{4} \text { Float }_{(t)}+\beta_{5} \text { Fixed }_{(t)}+\beta_{6} R_{N Y S E(t-1)}+\varepsilon_{(t)} \\
\sigma_{(t)}^{2}=\alpha_{0}+\alpha_{1} \varepsilon_{(t-1)}^{2}+\lambda_{1} \sigma_{(t-1)}^{2}+\pi_{1} \text { Float }_{(t)}+\pi_{2} \text { Fixed }_{(t)}+\pi_{3} \sigma_{F C}^{2}(t-1)+\pi_{4} \sigma_{F X}^{2}(t-1)+\pi_{5} \sigma_{\text {NYSE }}^{2}(t-1) \\
\varepsilon_{(t)} \mid I_{(t-1)} \sim N\left(0, \sigma^{2}\right)
\end{gathered}
$$

\section{Characteristics of the Return Generating Process}

The component model includes four conditional volatility terms, including the two components of total dollar returns in the conditional variance equation and one of NYSE index returns. For both model specifications in Tables 7 and 8, the testing of hypothesis H1 negates the properness of ARCH-M specification 
and accepts the GARCH-M process. Specifically, in Tables 9 and 10, all the six LR tests reject the null hypothesis of H1a at $1 \%$ level of significance. The significant $\chi^{2}$ statistics associated with the likelihood ratio tests for ARCH-M model could not adequately describe the return generating processes for the returns of these East Asian equity funds. However, H1b cannot be rejected at the $5 \%$ level for five out of the six country-specific funds in Table 9 and cannot be rejected for any of them in Table 10.

Table 8

Maximum Likelihood Estimates of Component GARCH-M $(1,1)$

\begin{tabular}{|c|c|c|c|c|c|c|c|}
\hline Coefficient & Thai Fund Inc. & $\begin{array}{l}\text { Thai } \\
\text { Fund Inc. }\end{array}$ & $\begin{array}{c}\text { Capital Indonesia } \\
\text { Inc. }\end{array}$ & $\begin{array}{l}\text { Fund First } \text { Philippine } \\
\text { Fund }\end{array}$ & Korea Fund Inc. & $\begin{array}{l}\text { Malaysia } \\
\text { Inc. }\end{array}$ & Fund \\
\hline \multirow[t]{2}{*}{$\overline{\beta_{1}}$} & $-0.006^{* * *}$ & -0.005 & 0.000 & -0.001 & $-0.002^{*}$ & -0.001 & \\
\hline & $(0.008)$ & (0.129) & $(0.701)$ & $(0.410)$ & (0.093) & (0.369) & \\
\hline \multirow[t]{2}{*}{$\beta_{2}$} & $0.091^{* * *}$ & -0.025 & -0.025 & -0.037 & 0.003 & 0.000 & \\
\hline & $(0.003)$ & $(0.402)$ & $(0.465)$ & $(0.255)$ & $(0.914)$ & (0.997) & \\
\hline \multirow[t]{2}{*}{$\beta_{3}$} & 0.115 & 0.000 & 0.074 & $0.204^{* *}$ & $0.171^{* *}$ & $0.301^{* * *}$ & \\
\hline & $(0.102)$ & (1.000) & $(0.132)$ & $(0.037)$ & $(0.047)$ & $(0.001)$ & \\
\hline \multirow[t]{2}{*}{$\phi$} & $4.972^{* *}$ & 2.750 & 1.988 & -0.262 & 1.228 & 1.859 & \\
\hline & $(0.021)$ & $(0.272)$ & $(0.441)$ & $(0.910)$ & $(0.535)$ & $(0.384)$ & \\
\hline \multirow[t]{2}{*}{$\beta_{4}$} & $-0.007^{* *}$ & -0.007 & -0.005 & 0.001 & 0.001 & $-0.007^{* *}$ & \\
\hline & $(0.044)$ & $(0.233)$ & $(0.161)$ & $(0.782)$ & $(0.405)$ & $(0.012)$ & \\
\hline \multirow[t]{2}{*}{$\beta_{5}$} & $0.004^{* *}$ & 0.003 & & 0.002 & & -0.001 & \\
\hline & $(0.048)$ & $(0.307)$ & & $(0.202)$ & & $(0.470)$ & \\
\hline \multirow[t]{2}{*}{$\beta_{6}$} & $0.161^{* *}$ & $0.233^{* * * *}$ & 0.048 & $0.221^{* * * *}$ & 0.052 & $0.215^{* * *}$ & \\
\hline & $(0.040)$ & $(0.006)$ & $(0.592)$ & $(0.000)$ & $(0.480)$ & $(0.001)$ & \\
\hline \multirow[t]{2}{*}{$\alpha_{0}$} & $0.000^{* * *}$ & $0.001^{* * *}$ & $0.000^{* *}$ & $0.000^{* * *}$ & 0.000 & $0.000^{*}$ & \\
\hline & $(0.000)$ & $(0.000)$ & $(0.011)$ & $(0.002)$ & $(0.136)$ & $(0.072)$ & \\
\hline \multirow[t]{2}{*}{$\alpha_{1}$} & $0.188^{* * *}$ & $0.095^{* * *}$ & $0.121^{* * *}$ & $0.158^{* * *}$ & 0.098 & $0.318^{* * *}$ & \\
\hline & $(0.000)$ & $(0.000)$ & $(0.000)$ & $(0.000)$ & $(0.000)$ & $(0.000)$ & \\
\hline \multirow[t]{2}{*}{$\lambda_{1}$} & $-0.515^{* * *}$ & $-0.498^{* * *}$ & $0.406^{* *}$ & $0.734^{* * *}$ & $0.782^{* * *}$ & $0.255^{* * *}$ & \\
\hline & $(0.000)$ & $(0.002)$ & $(0.019)$ & $(0.000)$ & $(0.000)$ & $(0.009)$ & \\
\hline \multirow[t]{2}{*}{$\pi_{1}$} & 0.000 & $0.001^{* * *}$ & $0.000^{* * *}$ & 0.000 & $0.000^{*}$ & $0.000^{* * *}$ & \\
\hline & $(0.246)$ & $(0.000)$ & $(0.005)$ & $(0.794)$ & $(0.083)$ & $(0.000)$ & \\
\hline \multirow[t]{2}{*}{$\pi_{2}$} & $-0.0003^{* * *}$ & $-0.001^{* * *}$ & & $-0.0001^{* * *}$ & & $0.0002^{* * *}$ & \\
\hline & $(0.000)$ & $(0.000)$ & & $(0.001)$ & & $(0.000)$ & \\
\hline \multirow[t]{2}{*}{$\pi_{3}$} & $0.658^{* * *}$ & $0.571^{* * *}$ & $0.132^{* *}$ & -0.005 & 0.069 & $0.186^{* * *}$ & \\
\hline & $(0.000)$ & $(0.000)$ & $(0.028)$ & $(0.704)$ & $(0.288)$ & $(0.005)$ & \\
\hline \multirow[t]{2}{*}{$\pi_{4}$} & $0.699^{* *}$ & -0.234 & 0.022 & 0.014 & 0.002 & -0.086 & \\
\hline & $(0.014)$ & $(0.348)$ & $(0.370)$ & $(0.387)$ & $(0.961)$ & $(0.555)$ & \\
\hline \multirow[t]{2}{*}{$\pi_{5}$} & $1.400^{* *}$ & $2.899^{* * *}$ & 0.063 & $0.359^{* *}$ & 0.108 & 0.315 & \\
\hline & $(0.024)$ & $(0.000)$ & $(0.797)$ & $(0.019)$ & $(0.206)$ & $(0.174)$ & \\
\hline Log Likelihood & 3165.775 & 3117.869 & 2445.460 & 2922.007 & 3269.064 & 3383.061 & \\
\hline \multirow[t]{2}{*}{ Engle's LM Test } & 0.140 & 0.961 & 0.057 & 0.906 & 0.572 & 0.160 & \\
\hline & (0.709) & $(0.327)$ & $(0.811)$ & $(0.341)$ & $(0.450)$ & $(0.689)$ & \\
\hline \# of observations & 1403 & 1403 & 1185 & 1422 & 1417 & 1414 & \\
\hline
\end{tabular}




\section{Hypotheses Tests: Relative Coefficients Tested Using Likelihood Ratio Test}

Tables 9 and 10 report the significance of relative coefficients of every hypothesis, tested using Likelihood Ratio tests, where $\mathrm{LR}=2(\mathrm{Lu}-\mathrm{Lr}) . L_{r} \mathrm{~s}$ come from the log likelihood values in Tables 7 and $8 ; L_{r} \mathrm{~s}$ are calculated from the restriction functions.

Table 9

Hypotheses Tests: Relative Coefficients Tested Using Likelihood Ratio Test Corresponding to Table 7

\begin{tabular}{lcccccc}
\hline \multirow{2}{*}{ Hypotheses } & \multirow{2}{*}{ Thai Fund Inc. } & Thai & Fund Inc. & Capital Indonesia & \multirow{2}{*}{ First Philippine Fund Korea Fund Inc. } & \multicolumn{2}{l}{ Malaysia } \\
Inc.
\end{tabular}

Notes. $^{* * * *},{ }^{* *}$, and ${ }^{*}$ indicate significance at the $1 \%, 5 \%$, and $10 \%$ levels, respectively.

Table 10

Hypotheses Tests: Relative Coefficients Tested Using Likelihood Ratio Test Corresponding to Table 8

\begin{tabular}{lcccccc}
\hline \multirow{2}{*}{ Hypotheses } & \multirow{2}{*}{ Thai Fund Inc. } & Thai & Fund Inc. & $\begin{array}{r}\text { Capital Indonesia } \\
\text { Fund Inc. }\end{array}$ & First Philippine Fund Korea Fund Inc. & $\begin{array}{l}\text { Malaysia } \\
\text { Inc. }\end{array}$ \\
\hline H1a & $72.702^{* * *}$ & $56.924^{* * *}$ & $31.952^{* * *}$ & $92.704^{* * * *}$ & $157.414^{* * *}$ & $60.404^{* * *}$ \\
H1b & -1.976 & 1.272 & 0.894 & 0.014 & 0.318 & 1.47 \\
H2 & $21.542^{* * *}$ & $35.114^{* * *}$ & $36.708^{* * *}$ & $17.87^{* * *}$ & 8.454 & $60.03^{* * *}$ \\
H3 & $44.268^{* * *}$ & 1.036 & 2.126 & 4.546 & 3.288 & $9.968^{* * *}$ \\
H4 & $58.178^{* * *}$ & $16.022^{* * *}$ & $7.388^{* *}$ & -2.642 & 2.886 & $20.986^{* * *}$ \\
\hline
\end{tabular}

Notes. ${ }^{* * * * * *}$, and ${ }^{*}$ indicate significance at the $1 \%, 5 \%$, and $10 \%$ levels, respectively.

Therefore, the GARCH process appears to describe the return generating process accurately, and the inclusion of time dependent variances is important. This is consistent with the long-memory GARCH term $\left(\sigma_{(t-1)}^{2}\right)$ being significant in the volatility equations reported in Tables 7 and 8 . For the estimation of returns for Thai fund in Table 7, while $\lambda_{1}$, the coefficient on the conditional variance of total returns, is insignificant; the significance of $\pi_{3}$ or $\pi_{4}$, as well as the significance of $\lambda_{1}$ in Table 8 , is evidence of the importance in examining component conditional volatilities and controlling for the exchange rate regime.

The intercept term in the volatility equation, $\alpha_{0}$, is positive and significant for all six East Asian equity funds in Table 7 and five out of six in Table 8, Korea as an exception. This indicates that in addition to time-dependent volatility; there exists a significant component of time-independent volatility.

\section{Effects of Exchange Rate Policy: Stabilization vs. Floating Rates}

Hypothesis H2 examine whether the application of floating exchange rates had an effect on the risk and return of country-specific equity funds. As shown in both Tables 9 and 10, H2 is rejected at the 1\% level for all six country-specific funds, which presents strong evidence of the effects of exchange rate policy.

To examine the emphasis of these regime effects, we focus on the coefficients in the mean and volatility equations. In the return function of both Tables 7 and 8 , the coefficients of Float $\left(\beta_{4}\right)$ are negative for the Thai fund and the Malaysia fund, while the coefficients of Fixed $\left(\beta_{5}\right)$ are positive for Thai fund. These effects are supposed to have provided the stimulus for the return to exchange rate stabilization and are consistent with the fact that Thailand changed from floating exchange rate regime back to intermediate exchange rate regime in 
January 1998 and Malaysia changed from floating exchange rate regime back to fixed exchange rate regime in September 1998.

For the volatility functions in both Tables 7 and 8, the coefficients of floating exchange regime are still significantly positive for four out of six funds, and that of Fixed is significantly negative for three out of four. Overall, it is consistent with the idea that the movement to floating exchange rates increased the time-independent portion of volatility.

\section{Exchange Rate Effects}

Lagged exchange rates and lagged conditional volatilities of exchange rate returns are included in the return and volatility equations to examine the effects of exchange rate factors on risk and return. In the conditional variance equation, the impacts of exchange rate volatility for these funds vary from country to country. $\pi_{4}$ is significantly positive for Thai fund whereas significantly negative for Malaysia fund. It indicates we could not predict the volatility of the equity fund return based on the exchange rate volatility.

In Tables 9 and 10, the null hypothesis of H3 is rejected for two funds, Thai fund and Malaysia fund, with coefficients $\left(\pi_{4}\right)$ significantly differ from 0 , indicating exchange rate volatility has an effect on the country-specific fund's return generating process. The insignificant $\chi^{2}$ statistics associated with other four funds suggest that risk aversion and hedging may have negated the effects of exchange rate risk.

\section{The Effects of Returns Denominated in the Foreign-Country Currency}

H4 examines whether lagged fund returns dominated in foreign currency and lagged conditional volatility of it have an effect on the country-specific fund's risk and return. In Tables 7 and 8, the conditional volatility of returns denominated in the foreign currency appears important in explaining the conditional volatility expressed in dollars for four funds: TTF, TF, IF, and MAY. The significant positive coefficients, $\pi_{3}$ s, for the four funds indicate when in-country return volatility increases one day, the next day the volatility of the four funds' returns denominated in dollars increases. And this in-country volatility influence the fund returns in dollars directly by the volatility pricing mechanism, as shown in the mean equations of component model. H4 is rejected for four of the six country-specific equity funds, as reported in both Tables 9 and 10.

\section{Alternative Specifications of the Model}

In the nominal sense, if a country is under the fixed exchange rate system, the changes (volatility) in foreign exchange rate are limited. When it starts floating, these changes become substantial. Moreover, Mussa (1986), Eichengreen (1988), Baxter and Stockman (1989), and Flood and Rose (1995) highlighted a positive relation between the shot-term volatility of the real exchange rate and the flexibility of the bilateral exchange rate regime. Thus, non-linearity may be present in the model. We incorporate three slope dummies in the GARCH-M model to test whether structural breaks effects exist (see Tables 11 and 12).

The hypotheses are basically the same. H2b is added, and $\mathrm{H} 3$ and $\mathrm{H} 4$ are modified as following:

H1a: The return generating process follows an ARCH-M specification: $\lambda_{1}=\pi_{3}=\pi_{4}=\pi_{5}=0$. Volatility is time dependent with a short memory; however, it is priced.

H1b: The return generating process follows a GARCH specification: $\phi=0$. The return generating process has a long memory and volatility is not a significant factor in pricing the country-specific equity funds.

H2a: The application of different exchange rate regimes had no effect on the risk of country-specific equity funds: $\phi=\pi_{1}=\pi_{2}=0$.

H2b: The choice of exchange rate regimes does not affect the returns of these funds: $\beta_{3}=\beta_{4}=\beta_{5}$. 
H3: Exchange rate effects have no impact on the country-specific fund's return generating process: $\beta_{3}=\beta_{4}$ $=\beta_{5}=\pi_{4}=0$.

H4: Foreign country effects have no impact on the country-specific fund's risk and return: component model: $\beta_{2}=\pi_{3}=0$.

The empirical results are consistent with the component model in Tables 7, 8, 9, and 10. Specifically, Table 12 shows that the testing of hypothesis $\mathrm{H} 1$ negates the properness of ARCH-M specification and could not reject GARCH-M process for all six East Asian equity funds.

Table 11

Maximum Likelihood Estimates of Component GARCH-M $(1,1)$

\begin{tabular}{|c|c|c|c|c|c|c|}
\hline Coefficient & Thai Fund Inc. & $\begin{array}{l}\text { Thai Capital Fund } \\
\text { Inc. }\end{array}$ & $\begin{array}{l}\text { Indonesia Fund } \\
\text { Inc. }\end{array}$ & $\begin{array}{l}\text { First Philippine } \\
\text { Fund }\end{array}$ & Korea Fund Inc. & $\begin{array}{l}\text { Malaysia Fund } \\
\text { Inc. }\end{array}$ \\
\hline \multirow[t]{2}{*}{$\overline{\beta_{1}}$} & $0.532^{* * *}$ & $-0.315^{*}$ & 0.079 & 0.060 & 0.092 & $0.429^{* * *}$ \\
\hline & $(0.001)$ & $(0.075)$ & $(0.115)$ & $(0.805)$ & $(0.374)$ & $(0.000)$ \\
\hline \multirow[t]{2}{*}{$\beta_{2}$} & $-0.002^{* *}$ & -0.001 & 0.000 & 0.001 & $-0.002^{*}$ & -0.001 \\
\hline & $(0.045)$ & (0.165) & (0.996) & $(0.451)$ & $(0.067)$ & $(0.318)$ \\
\hline \multirow[t]{2}{*}{$\beta_{3}$} & $0.102^{* * *}$ & -0.030 & -0.022 & -0.035 & 0.007 & 0.013 \\
\hline & $(0.003)$ & (0.369) & $(0.522)$ & $(0.264)$ & $(0.816)$ & $(0.697)$ \\
\hline \multirow[t]{2}{*}{$\beta_{4}$} & $0.332^{* *}$ & $0.284^{*}$ & 0.198 & $0.297^{* * *}$ & $0.514^{* * *}$ & -0.019 \\
\hline & (0.019) & $(0.054)$ & $(0.396)$ & $(0.005)$ & $(0.006)$ & $(0.923)$ \\
\hline \multirow[t]{2}{*}{$\beta_{5}$} & 0.156 & -0.001 & & -1.170 & & 0.156 \\
\hline & $(0.503)$ & $(0.997)$ & & $(0.304)$ & & $(0.627)$ \\
\hline \multirow[t]{2}{*}{$\phi$} & 1.583 & -0.273 & -0.989 & -2.350 & 2.425 & 0.027 \\
\hline & $(0.318)$ & $(0.844)$ & $(0.404)$ & $(0.153)$ & (0.129) & $(0.984)$ \\
\hline \multirow[t]{2}{*}{$\beta_{6}$} & $0.150^{*}$ & $0.265^{* * *}$ & 0.051 & $0.223^{* * *}$ & 0.050 & $0.216^{* * *}$ \\
\hline & $(0.077)$ & $(0.003)$ & $(0.562)$ & $(0.000)$ & $(0.500)$ & $(0.001)$ \\
\hline \multirow[t]{2}{*}{$\alpha_{0}$} & $0.000^{* * *}$ & $0.000^{* * *}$ & $0.000^{* *}$ & $0.000^{* * *}$ & 0.000 & $0.000^{*}$ \\
\hline & $(0.000)$ & $(0.005)$ & $(0.015)$ & $(0.001)$ & $(0.107)$ & $(0.076)$ \\
\hline \multirow[t]{2}{*}{$\alpha_{1}$} & $0.084^{*}$ & 0.047 & $0.107^{* * *}$ & $0.160^{* * *}$ & $0.096^{* * *}$ & $0.270^{* * *}$ \\
\hline & $(0.052)$ & $(0.178)$ & $(0.000)$ & $(0.000)$ & $(0.000)$ & $(0.000)$ \\
\hline \multirow[t]{2}{*}{$\lambda_{1}$} & $-0.330^{* *}$ & -0.277 & $0.385^{* *}$ & $0.727^{* * *}$ & $0.800^{* * *}$ & $0.235^{* *}$ \\
\hline & (0.019) & $(0.317)$ & $(0.048)$ & $(0.000)$ & $(0.000)$ & $(0.035)$ \\
\hline \multirow[t]{2}{*}{$\pi_{1}$} & $0.000^{*}$ & 0.000 & $0.000^{* * *}$ & 0.000 & $0.000^{*}$ & $0.000^{* * *}$ \\
\hline & $(0.071)$ & (0.187) & $(0.007)$ & $(0.570)$ & (0.089) & $(0.000)$ \\
\hline \multirow[t]{2}{*}{$\pi_{2}$} & $0.000^{* * *}$ & $0.000^{* * * *}$ & & $0.000^{* * *}$ & & $0.000^{* * *}$ \\
\hline & $(0.000)$ & $(0.003)$ & & $(0.000)$ & & $(0.000)$ \\
\hline \multirow[t]{2}{*}{$\pi_{3}$} & $0.598^{* * *}$ & $0.591^{* * *}$ & $0.152^{* *}$ & $-0.029^{* *}$ & 0.052 & $0.226^{* * *}$ \\
\hline & $(0.000)$ & $(0.001)$ & $(0.039)$ & $(0.012)$ & $(0.441)$ & $(0.008)$ \\
\hline \multirow[t]{2}{*}{$\pi_{4}$} & $0.972^{* * *}$ & -0.191 & 0.025 & 0.016 & 0.000 & -0.053 \\
\hline & $(0.000)$ & $(0.470)$ & $(0.382)$ & $(0.331)$ & $(0.991)$ & $(0.768)$ \\
\hline \multirow[t]{2}{*}{$\pi_{5}$} & $1.175^{* *}$ & $2.438^{* * *}$ & -0.029 & $0.498^{* * *}$ & 0.118 & 0.284 \\
\hline & $(0.039)$ & $(0.004)$ & $(0.916)$ & $(0.002)$ & $(0.140)$ & $(0.255)$ \\
\hline Log Likelihood & 3172.477 & 3128.178 & 2448.574 & 2922.191 & 3270.754 & 3379.203 \\
\hline \multirow[t]{2}{*}{ Engle's LM Test } & 0.055 & 0.073 & 0.011 & 0.804 & 0.565 & 0.052 \\
\hline & $(0.815)$ & $(0.787)$ & $(0.916)$ & $(0.370)$ & $(0.452)$ & $(0.820)$ \\
\hline \# of observations & 1403 & 1403 & 1185 & 1422 & 1417 & 1414 \\
\hline
\end{tabular}

Notes. $^{* * *},{ }^{* *}$, and ${ }^{*}$ indicate significance at the $1 \%, 5 \%$, and $10 \%$ levels, respectively. 


\section{Maximum Likelihood Estimates of Component GARCH-M (1,1) and Hypotheses Tests}

Tables 11 and 12 present the results for the following GARCH-M model using maximum likelihood estimation, as well as the hypotheses test of relative coefficients using likelihood ratio test. The sample starts from January 1, 1995, and ends with December 31, 2000.

$$
\begin{aligned}
& R_{S(t)}=\beta_{1}+\beta_{2} R_{F C(t-1)}+\beta_{3} * \text { Float } * R_{F X(t-1)}+\beta_{4} * \text { Intermediate } * R_{F X(t-1)}+\beta_{5} * F i x * R_{F X(t-1)}+\phi \sigma^{2}(t)+\beta_{6} R_{N Y S E(t-1)}+\varepsilon_{(t)} \text { (7a) } \\
& \sigma_{(t)}^{2}=\alpha_{0}+\alpha_{1} \varepsilon_{(t-1)}^{2}+\lambda_{1} \sigma_{(t-1)}^{2}+\pi_{1} \text { Float }_{(t)}+\pi_{2} \text { Fixed }_{(t)}+\pi_{3} \sigma_{F C^{(t-1)}}^{2}+\pi_{4} \sigma_{F X}^{2}(t-1)+\pi_{5} \sigma_{\text {NYSE }}^{2}(t-1) \\
& \varepsilon_{(t)} \mid I_{(t-1)} \sim N\left(0, \sigma^{2}\right)
\end{aligned}
$$

Table 11 reports the coefficients of the above GARCH-M model. The $p$-value for the coefficient estimates are reported in the parentheses below the estimates. The log likelihood value of each equation is reported at the bottom. Engle's LM test against first-order serial correlation in the residuals is also specified.

Table 12 reports the significance of relative coefficients of every hypothesis (except $\mathrm{H} 2 \mathrm{~b}$, where the $t$-test is used to examine the equality of relevant coefficients), tested using likelihood ratio tests, where LR = 2(Lu-Lr).

\begin{tabular}{|c|c|c|c|c|c|c|}
\hline Hypotheses & Thai Fund Inc. & $\begin{array}{l}\text { Thai Capital } \\
\text { Fund Inc. }\end{array}$ & $\begin{array}{l}\text { Indonesia } \\
\text { Fund Inc. }\end{array}$ & First Philippine Fund & Korea Fund Inc. & $\begin{array}{l}\text { Malaysia Fund } \\
\text { Inc. }\end{array}$ \\
\hline H1a & $93.66^{* * *}$ & $63.824^{* * *}$ & $38.338^{* * *}$ & $91.432^{* * *}$ & $139.968^{* * *}$ & $58.23^{* * *}$ \\
\hline $\mathrm{H} 1 \mathrm{~b}$ & 1.174 & 0.044 & 0.824 & 2.258 & 2.182 & 0.002 \\
\hline $\mathrm{H} 2 \mathrm{a}$ & $16.924^{* * *}$ & $18.91^{* * *}$ & $32.386^{* * *}$ & $18.61^{* * *}$ & $8.18^{* *}$ & $49.15^{* * *}$ \\
\hline H2b: $\beta_{3}=\beta_{4}$ & -1.167 & -1.413 & -0.935 & -1.254 & $-2.399^{* *}$ & 0.144 \\
\hline$\beta_{3}=\beta_{5}$ & 0.190 & 0.131 & & -0.974 & & 0.423 \\
\hline$\beta_{4}=\beta_{5}$ & 0.648 & 1.402 & & 1.280 & & -0.465 \\
\hline H3 & $17.654^{* * *}$ & 6.612 & 2.328 & $8.092^{*}$ & 7.134 & $14.492^{* * *}$ \\
\hline $\mathrm{H} 4$ & $42.75^{* * *}$ & $12.468^{* * *}$ & $7.586^{* *}$ & 0.94 & 1.298 & $19.866^{* * *}$ \\
\hline
\end{tabular}

Table 12

Hypotheses Tests: Relative Coefficients Tested Using Likelihood Ratio Test Corresponding to Table 11

Notes. $^{* * *},{ }^{* *}$, and ${ }^{*}$ indicate significance at the $1 \%, 5 \%$, and $10 \%$ levels, respectively.

The null hypothesis of H2a, examining whether the application of floating exchange rates had an effect on the risk and return of country-specific equity funds, is also rejected for all six funds. H2b is tested by pairs using $t$-test. For five out of six funds, the equality of relevant coefficients could not be rejected, showing structural break is not a problem for our component model.

Similar to the result in Tables 9 and 10, H3 is rejected for two funds, Thai fund and Malaysia fund, at 1\%, and another one fund, First Philippine fund, at 10\%, indicating exchange rate volatility has an effect on the country-specific fund's return generating process; H4 is rejected for four of the six country-specific equity funds, as reported in Table 12, indicating lagged fund returns dominated in foreign currency and lagged conditional volatility of it have an effect on the country-specific fund's risk and return.

\section{Conclusions}

This research uses the returns from six East Asian country-specific equity funds during a period of financial crises: (1) to examine the return generating processes associated with the funds; (2) to evaluate the effects of component returns and their volatility on the dollar denominated returns and volatility of U.S., international investors; and (3) to evaluate the effects of exchange rate regimes on risk and return. 
The appropriateness of the GARCH model indicates that returns of country-specific equity funds have long and short time-dependent components to volatility that are not adequately captured by simple regression techniques.

The component model indicates that the conditional volatility of dollar denominated returns is important in pricing the country-specific mutual funds only in Thailand. With regards to the effects on volatility, both the conditional variances associated with the exchange rate returns and the returns denominated in the foreign currencies show some importance, especially the conditional variances associated with the returns denominated in the foreign currencies. With regards to the effects of return component, the exchange rate returns have greater effect on the fund returns than foreign currency dominated returns.

The effects associated with the exchange rate regimes are very interesting. In both the mean return equation and the conditional variance equation, there is evidence of significant effects of the change in exchange rate regimes. As expected the implementation of floating exchange rates is associated with an decrease in mean return as captured by the significant Float $(t)$ variables in the mean return equations. However, most Float $(t)_{\text {S }}$ are associated with an increase in volatility as captured by the significant Float $(t)$ variables in the conditional variance equations. This indicates that relaxation of exchange rate regulation increases the volatility of the fund return in dollars, whereas decrease fund returns in dollars.

This research provides evidence of the importance of examining component returns. The differing effects of returns in the foreign currency versus returns due to changing exchange rates are captured. Some of the inconsistencies in the signs of coefficients across country-specific equity funds suggest the need for further research.

\section{References}

Asian Development Bank. (1999). Asian development outlook. Manila: Asian Development Bank.

Baxter, M., \& Stockman, A. (1989). Business cycles and the exchange-rate regime: Some international evidence. Journal of Monetary Economics, 23, 377-400.

Bekaert, G., \& Urias, M. S. (1996). Diversification, integration, and emerging market closed-end funds. Journal of Finance, 51, 835-869.

Bekaert, G., \& Urias, M. S. (1999). Is there a free lunch in emerging market equities? Journal of Portfolio Management, 25, 83-95.

Ben-Zion, U., Choi, J. J., \& Hauser, S. (1996). The price linkages between country funds and national stock markets: Evidence from cointegration and causality tests of Germany, Japan, and U.K. funds. Journal of Business Finance and Accounting, 23, 1005-1017.

Bollerslev, T. (1986). Generalized autoregressive conditional heteroskedasticity. Journal of Econometrics, 31, 307-327.

Chang, E., Eun, C. S., \& Kolodny, R. (1995). International diversification through closed-end country funds. Journal of Banking and Finance, 19, 1237-1263.

Cheetham, R. (1998). Asia Crisis. Working Paper, Proceedings from the Conference of U.S.-ASEAN-Japan Policy Dialogue. School of Advanced International Studies of Johns Hopkins University, Washington, D.C..

Chiang, T. C., \& Kim, D. (2003). On country-fund price behavior: An empirical analysis of cointegrating factors. Advances in Financial Planning and Forecasting, 11, 85-112.

Eichengreen, B. (1988). Real exchange rate behavior under alternative international monetary regimes: Interwar evidence. European Economic Review, 32, 363-371.

Eichengreen, B., \& Hausmann, R. (1999). Exchange rates and financial fragility. NBER Working Paper No. 7418. Massachusetts: National Bureau of Economic Research.

Elyasiani, E., \& Mansur, I. (1998). Sensitivity of the bank stock returns distribution to changes in the level and volatility of interest rate: A GARCH-M model. Journal of Banking and Finance, 22, 535-563.

Engle, R. F. (1982). Autoregressive conditional heteroscedasticity with estimates of the variance of United Kingdom inflation. 
Econometrica, 50, 987-1007.

Engle, R. F., Lilien, D. M., \& Robins, R. P. (1987). Estimating time varying risk premia in the term structure: The ARCH-M model. Econometrica, 55, 391-407.

Flood, R., \& Rose, A. (1995). Fixing exchange rates: A virtual quest for fundamentals. Journal of Monetary Economics, $36,3-37$.

Grubel, H. G., \& Fadner, K. (1971). The interdependence of international equity markets. Journal of Finance, 26, 89-94.

Hardouvelis, G., LaPorta, R., \& Wizman, T. A. (1994). What moves the discount on closed-end country funds. In J. A. Frankel (Ed.), The internationalization of equity markets (pp. 345-397). Chicago: University of Chicago Press.

Kim, C., \& Lee, J. (2008). Exchange rate regime and monetary policy independence in East Asia. Pacific Economic Review, 13, 155-170.

Lee, B. S., \& Hong, G. (2002). On the dual characteristics of closed-end country funds. Journal of International Money and Finance, 21, 589-618.

Levy-Yeyati, E., \& Sturzenegger, F. (2005). Classifying exchange rate regimes: Deeds and words. European Economic Review, 49, 1603-1635.

Mussa, M. (1986). Nominal exchange rate regimes and the behavior of real exchange rates: Evidence and implications. Carnegie-Rochester Conference Series on Public Policy, 25, 117-214.

Panton, D. B., Lessig, V. P., \& Joy, O. M. (1976). Co-movement of international equity markets: A taxonomic approach. Journal of Financial and Quantitative Analysis, 11, 415-432.

PemPel, T. J. (1999). The politics of Asian economic crisis. New York: Cornell University Press.

Reinhart, C. M., \& Rogoff, K. S. (2004). The modern history of exchange rate arrangements: A reinterpretation. Quarterly Journal of Economics, 119, 1-48.

Richard, J. E., \& Wiggins, J. B. (2000). The information content of closed-end country fund discounts. Financial Services Review, 9, 171-181.

Ripley, D. M. (1973). Systematic elements in the linkage of national stock market indices. The Review of Economics and Statistics, 55, 356-361.

Saxena, S. (2008). Capital flows, exchange rate regime and monetary policy. BIS Papers No. 35, Bank for International Settlements.

Taylor, M. P., \& Tonks, I. (1989). The internationalization of stock markets and the abolition of U.K. exchange controls. Review of Economics and Statistics, 71, 332-336.

Tsutsui, Y., \& Hirayama, K. (2004). Are international portfolio adjustments a cause of comovements in stock prices? Pacific-Basin Finance Journal, 12, 463-478.

World Bank. (1999). Global development finance. Washington, D.C.: The World Bank. 


\section{Appendix A}

Table A1 reports the de facto classifications of exchange rate regimes for East Asian countries by Reinhart and Rogoff (2004). The de facto exchange rate regimes are classified into three groups: fixed exchange rate, intermediate exchange rate, and floating exchange rate.

Table A1

De Facto Exchange Rate Regimes in East Asia

\begin{tabular}{|c|c|c|c|c|}
\hline \multirow{2}{*}{ Country } & \multicolumn{2}{|l|}{ Period } & \multicolumn{2}{|l|}{ Exchange rate regime classification } \\
\hline & From & To & Narrow & Broad \\
\hline \multirow{7}{*}{ Philippines } & Dec. 72 & Sep. 83 & De facto crawling band around US\$ & \multirow{4}{*}{ Intermediate } \\
\hline & Oct. 83 & Feb. 85 & Managed floating & \\
\hline & Mar. 85 & Apr. 92 & De facto crawling peg to US\$ & \\
\hline & May 92 & Aug. 95 & De facto band around US\$ & \\
\hline & Sep. 95 & Jun. 97 & De facto peg to US\$ & Fixed \\
\hline & Jun. 97 & Dec. 97 & Freely floating/free falling ${ }^{*}$ & Floating \\
\hline & Dec. 97 & Dec. 01 & Managed floating & Intermediate \\
\hline \multirow{4}{*}{ Thailand } & Oct. 63 & Mar. 78 & Peg to US\$ & \multirow{2}{*}{ Fixed } \\
\hline & Mar. 78 & Jul. 97 & De facto peg to US\$ & \\
\hline & Jul. 97 & Jan. 98 & Freely floating/free falling* & Floating \\
\hline & Jan. 98 & Dec. 0l & Manage floating & Intermediate \\
\hline \multirow{4}{*}{ Indonesia } & Dec. 70 & Aug. 71 & Peg to US\$ & Fixed \\
\hline & Aug. 71 & Oct. 78 & De facto crawling band to US\$ & \multirow{2}{*}{ Intermediate } \\
\hline & Nov. 78 & Jul. 97 & De facto crawling peg to US\$ & \\
\hline & Aug. 97 & Jan. 02 & Freely floating/free falling* & Floating \\
\hline \multirow{5}{*}{ Korea } & May 74 & Feb. 80 & Peg to US\$ & Fixed \\
\hline & Feb. 80 & Nov. 94 & Pre-announced crawling band & \multirow{2}{*}{ Intermediate } \\
\hline & Nov. 94 & Nov. 97 & De facto crawling peg to US\$ & \\
\hline & Dec. 97 & Jun. 98 & Freely falling* & \multirow{2}{*}{ Floating } \\
\hline & Jul. 98 & Dec. 01 & Freely floating & \\
\hline \multirow{4}{*}{ Malaysia } & Jun. 67 & Aug. 75 & Peg to pound sterling & Fixed \\
\hline & Sep. 75 & Jul. 97 & Limited flexibility wrt US\$ & Intermediate \\
\hline & Aug. 97 & Sep. 98 & Freely floating/free falling & Floating \\
\hline & Sep. 98 & Dec. 01 & Pegged arrangement & Fixed \\
\hline
\end{tabular}

Note. ${ }^{*}$ Freely falling is a new separate category for countries whose 12 -month rate of inflation is above $40 \%$ (Kim \& Lee, 2008). 